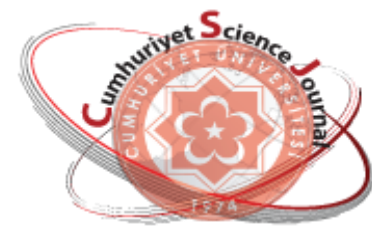

e-ISSN: $2587-246 X$

ISSN: $2587-2680$

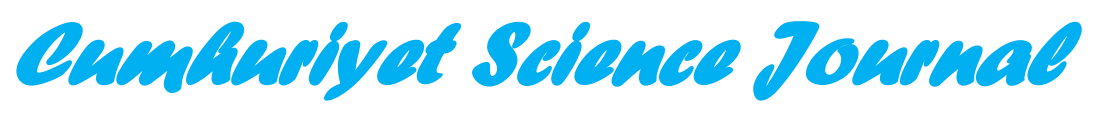

CST

Cumhuriyet Sci. J., Vol.38-4 (2017) 731-737

\title{
Spectral Classification in Lithological Mapping; A Case Study of Matched Filtering
}

\author{
Onder GURSOY ${ }^{1}$, Oktay CANBAZ ${ }^{2 *}$, Ahmet GOKCE ${ }^{2}$, Rutkay ATUN \\ ${ }^{1}$ Cumhuriyet University, Dept. of Geomatics Engineering, 58140, Sivas / TURKEY \\ ${ }^{2}$ Cumhuriyet University, Dept. of Geological Engineering, 58140, Sivas / TURKEY
}

\begin{abstract}
In recent years, a large number of studies have been carried out on determining geological characteristics using remote sensing studies and their usefulness. The integrating satellite images and terrestrial spectral data are used distinguishing lithologies in geological units. The use of remote sensing images helps to save time and to reduce the cost of mapping works. In this study, the usability of ASTER SWIR images in distinguishing rock types and in determination of contacts between lithological units in Kösedağ area between Zara and Suşehri towns of Sivas Province. Syenitic, andesitic, basaltic and ophiolitics rocks are cropt out in this area. Spectral signatures of the representative samples from these rock types were measured via ASD spectroradiometer. The signatures were resampled to ASTER SWIR bandwidth as end member. Matched filtering method was performed on the images for spectral classification. The results showed that distinguishing of the mentioned rock types is possible and the boundaries between rock types on the spectral images are mostly coincided with the boundaries on the 1:100.000 scale geological map of the study area.
\end{abstract}

Keywords: Remote sensing, Zara-Suşehri (Sivas), Geology, ASTER, Matched Filtering.

\section{Litolojik Haritalamada Spektral Sınıflandırma: Eşleşen Filtreleme Örnek Çalışması}

\begin{abstract}
Özet: Son yıllarda, jeolojik özelliklerin uzaktan algılama ile belirlenmesi ve yararlılı̆̆ konusunda çok sayıda çalışma gerçekleştirilmiştir. Jeolojik birimler içindeki kaya türlerini ayırtlamak için uydu görüntüleri ve yersel spectral ölçme verileri kullanılmaktadır. Uzaktan algılama görüntülerinin kullanılması harita çalışmalarının maliyetini düşürmekte ve zaman tasarrufu sağlamaktadır. Bu çalışmada, Sivas ili Zara ve Suşehri ilçeleri arasında yer alan Kösedağ yöresinde kayaç türlerini ayırtlamak ve litolojik birimler arasındaki dokunakları belirlemek için ASTER SWIR görüntülerinin kullanılabilirliği araştırılmaktadır. Bu sahada, ofiyolitik, andezitik, bazaltik ve siyenitik kayaçlar yüzeylemektedir. Bu kayaç türlerinden alınmış temsili örneklerin spektral özellikleri/belirteçleri ASD spectroradyometre ile ölçülerek belirlenmiştir. Belirlenmiş özellikler, referans spektra ASTER SWIR bant dalga boyu aralıklarına yeniden örneklenmiştir. Spektral sınıflandırma için eşleşen filtreleme (Matched filtering) yöntemi uygulanmıştır. Sonuçlar, belirtilen kayak tiplerinin ayıtlanmasının mümkün olduğunu ve aralarındaki sınırların inceleme alanının 1/100.000 ölçekli jeolojik haritası üzerinde çizilmiş dokunaklar ile çakıştığını göstermiştir.
\end{abstract}

Anahtar Kelimeler: Uzaktan algılama, Zara-Suşehri (Sivas), Jeoloji, ASTER, Eşleşen Filtreleme. 


\section{INTRODUCTION}

Geological mapping is a process which is very difficult and requires a long time, high cost study on the field. Detection and classification of lithological units spread over large areas due to the development of remote sensing technology is important for geological mapping and detecting of hydrothermal alteration areas [1-3].

In satellite images of low spatial resolution, many objects couldn't be detected due to the components of the scene are smaller than pixels [4]. Extraction fractions related to pure features or endmembers [5], many spectral unmixing [6] techniques are used. Estimating and mapping the total area covered by leafy spurge and found, Williams and Hunt [7] used the mixture-tuned matched filtering (MTMF) methodthe spectral unmixing technique these to be very useful. Using spectral information in spectral unmixing techniques, spatial alteration in absolutely pristine areas could be mapped [8].

This study was aimed to test the usability of Matched Filtering (MF) which is one of the spectral classification method to identify the lithological characteristics of geological units and determining the contact between them by using the Advanced Spaceborne Thermal Emission and Reflection Radiometer (ASTER) image ASTER is one of remote sensors which is suitable in order to geological mapping [3, 9-15]. ASTER is a multispectral imaging sensor that measures electromagnetic radiation emitted and reflected from Earth's surface and atmosphere in 14 spectral bands which include: three visible and near infrared radiation (VNIR); six shortwave infrared radiation (SWIR) bands; and five recording thermal infrared radiation (TIR).

The study area is located between Zara-Susehri Towns (Sivas Province), northeast of Central Anatolia (Fig.1a). The study area is quite rich in terms of geological unit diversity such as magmatic, volcanic, sedimentary and ophiolitic rocks namely; Late Cretaceous-Paleocene Refahiye Ophiolithic melange, Eocene Kösedă Syenite, Eocene Karataş Volcanics and Miocene Pliocene terrestrial sedimentary rocks (Fig. 1b). Late Cretaceous-Paleocene Refahiye Ophiolithic Melange consists mainly of serpentinized peridotitic rocks $[16,17]$. The Eocene Kösedağ Pluton has syenitic and quartz syenitic composition [18, 19]. The Eocene Karataş Volcanics include lavas, tuffs and agglomerates of basaltic, basaltic andesitic, trachytic, trachyandesitic, andesitic compositions [20]. The presence of granitic, volcanic and ophiolitic rocks and hydrothermal alteration products make the area as remarkable in terms of ore prospecting target area. 


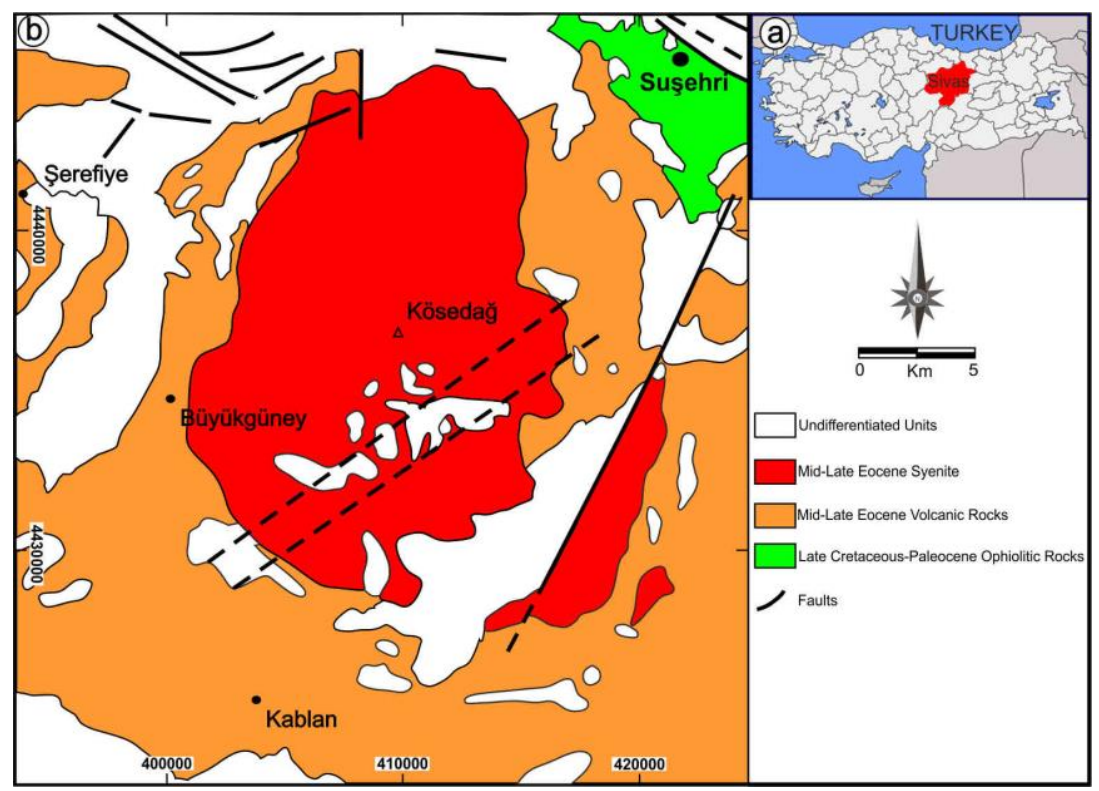

Figure 1. a) Map of Turkey. b) Geological map of the close to the study area (modified after MTA geological maps and [20]).

\section{MATERIALS AND METHODOLOGY}

It was collected representative samples of geological units consist of syenite, andesite, basalt and ophiolitic rocks. Petrographic investigations were carried out this rock units by polarizing microscopes in Cumhuriyet University Geological Engineering Laboratories. Spectral measurements were carried out in Cumhuriyet University, Geomatics Engineering Laboratories for each representative rock samples via spectroradiometer with self illuminated contact probe lens. The spectoradiometer measurements within the wavelenght range of of 350-2500 nm were resampled to spectral region ASTER SWIR bands to be used as endmember (Fig 2). It is necessary to correct the sensor properties for the known crosstalk error, and this is also the initial processing of the Aster image [21]. Operations such as crosstalk adjustment, radiance calibration and reflectance transformation are included in the applications of imaging spectrometry analysis to improve utility of atmospheric correction. [22-24]. For this reason, atmospheric and radiometric correction was applied on the image to reduce the systematic errors on the image to a minimum level and to reduce the effects of negative scattering and absorption of the atmosphere [6]. The atmospheric correction of the remote sensing image was performed with the values calculated by Moderate Resolution Transmittance (MODTRAN) algorithm. [25] (Fig.3) Many types of spectral mixture analyses are used for the spectral discrimination of materials in any pixel [7, 26, 27]. In this study, Matched Filtering (MF) was used for spectral unmixing. Matched Filtering is used for deriving the proportions of the spectral endmember for each pixel. MF is one of the spectral classification method was used in order to determine the boundaries and characteristics of geological units. MF is also a spectral classification method that suppresses the response of the composite by maximing the response of the reference endmembers [28]. MF result was carried out the syenitic, andesitic, basaltic and ophiolitic rocks endmember. In figure 4 , the colors of units demonstrate on the legend. 

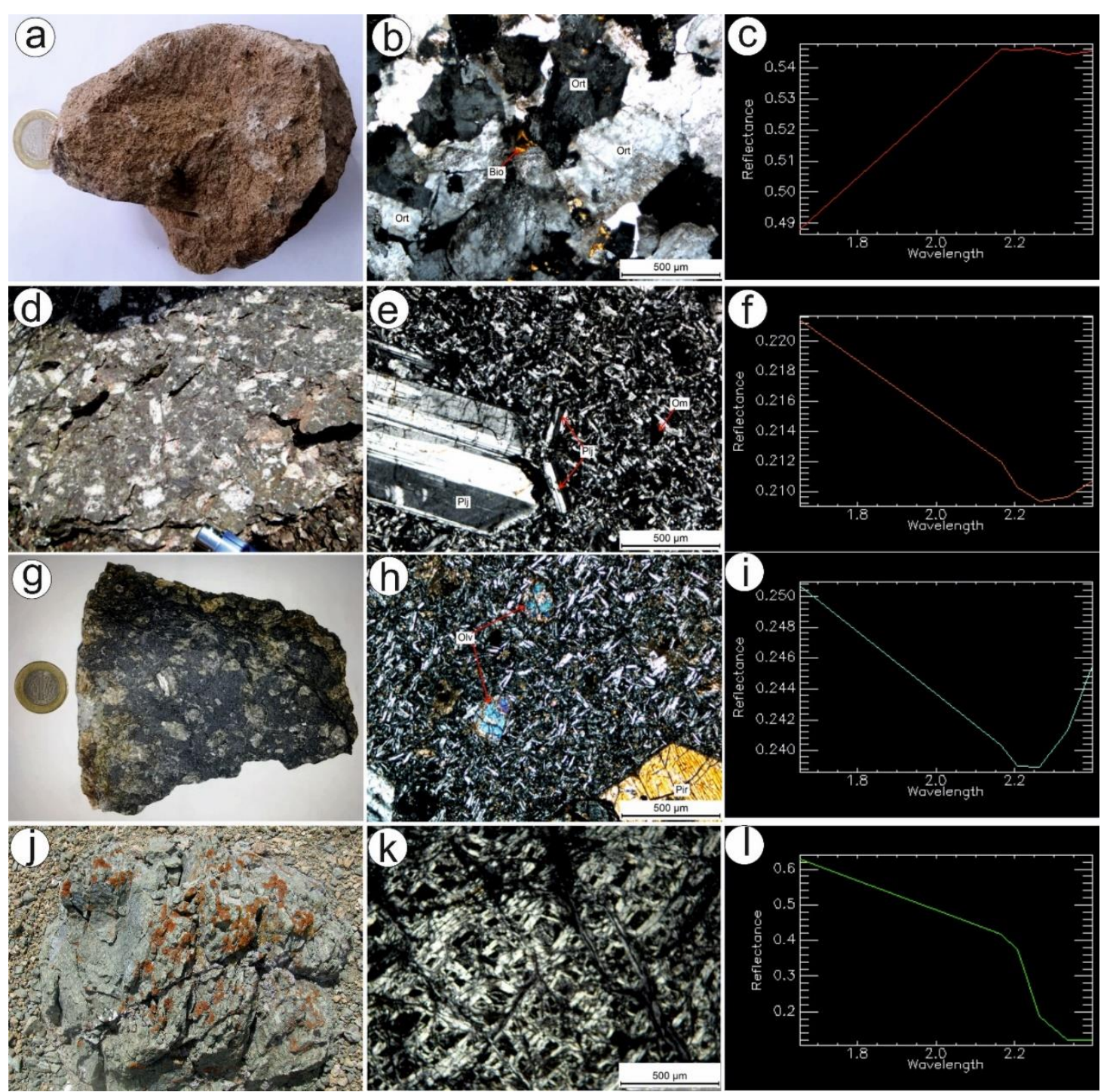

Figure 2. a,d,g,j) Samples of syenite, andesite, basalt and serpentized peridotite. $\mathbf{b}, \mathbf{e}, \mathbf{h}, \mathbf{k})$ thin sections of the rock samples. c,f,i,l) Spectral signatures that were resampled to ASTER SWIR bands width.

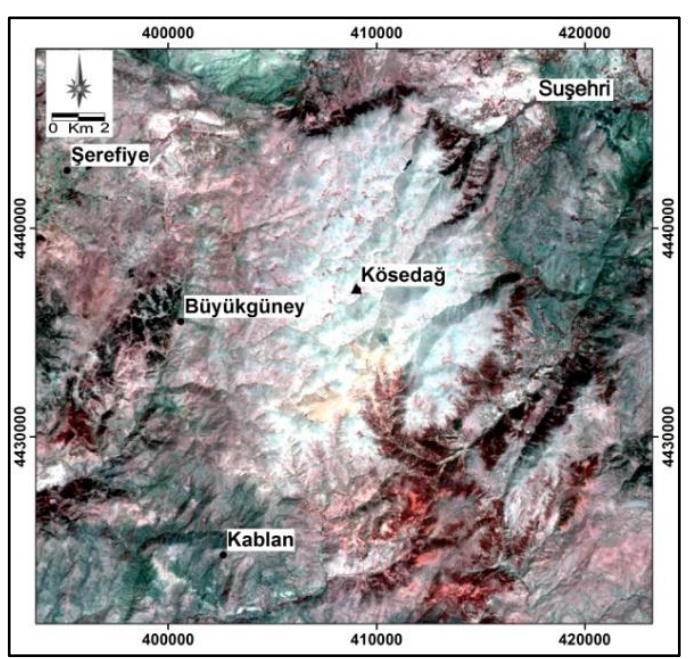

Figure 3. ASTER SWIR image (R:4, G:5:,B:6) that was corrected radiometrically and atmospherically.

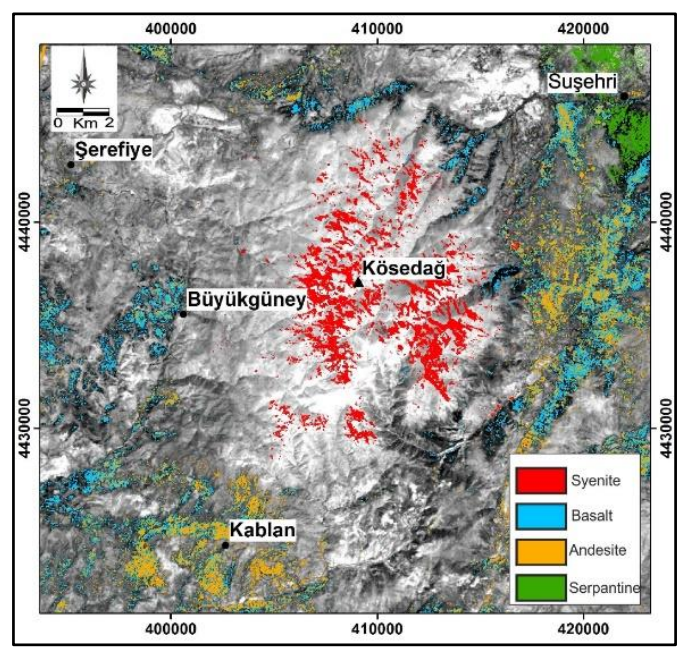

Figure 4. Results of matched filtering (MF). 


\section{DISCUSSIONS OF RESULTS AND CONCLUSIONS}

In this study, it was investigated to determine the geology and contact zones of rocks between ZaraSuşehri (Sivas) by using ASTER SWIR image. The descriptions of the basalt, andesite, syenite and serpentine representative samples were collected from the study area, were carried out on the polarizing microscope in the laboratories.

The various rock types were demonstrated in different colors on the matched filtering map. According to the matched filtering results, the detected areas of ophilite, basalt, andesite and syenite are coincided with the areas on the 1:100.000 scaled geology map although they do not completely cover the rock groups. We can list the reasons of these results, classical geology maps are not enough to validate the data in the remote sensing classification of maps, since they show the lithology of the area by formless geometry, the changes caused by the atmospheric and hydrothermal conditions on the rock surfaces, presence of the rock groups including very variety components and the fact that these components are intricately intertwined. The results point out that spectral unmixing methods such as MF could be reduced time and cost of mapping works.

The most important disadvantage of this method is the problem of spectral mixing. The most incorrect assumption made with MF is the last members selected to classify the image represent the pure spectra of a reference material. The use of hyperspectral images with higher spatial resolution overcomes this problem.

\section{Acknowledgments}

The Research Foundation of Cumhuriyet University supported this study (Project No: M613)

\section{REFERENCES}

[1]. Kruse F.A. Mapping surface mineralogy using imaging spectrometry, Geomorphology 2011; 137: 41-56
[2]. Kruse F.A., Perry S.F. Mineral Mapping Using Simulated Worldview-3 Short-WaveInfrared Imagery, Remote Sensing, 2013, 5, 2688-2703; doi:10.3390/rs5062688

[3]. Canbaz O., Gürsoy, Ö., Gökce A., Determination of Hydrothermal Alteration Areas by Aster Satellite Images: Ağmaşat Plato- Zara (Sivas) / Turkey Sample. Cumhuriyet Science Journal. 2017; 38 (3)419-426.

[4]. Strahler A.H., Woodcock C.E., Smith J.A. On the Nature of Models in Remote Sensing. Remote Sensing of Environment 1986; 20 : 121-139.

[5]. Van der Meer F., de Jong S.M., Improving the Results of Spectral Unmixing of Landsat Thematic Mapper Imagery by Enhancing the Orthogonality of End-Members. International Journal of Remote Sensing 2000; 21: 27812797.

[6]. Lu D., Weng Q., Spectral Mixture Analysis of the Urban Landscape in Indianapolis with Landsat ETM+ Imagery. Photogrammetric Engineering and Remote Sensing 2004; 70: 1053-1062.

[7]. Williams A.P., Hunt E.R.,. Estimation of Leafy Spurge Cover from Hyperspectral Imagery Using Mixture Tuned Matched Filtering. Remote Sensing of Environment 2002; 82: 446-456.

[8]. Beiranvand Pour A., Hashim M.,. Application of Advanced Spaceborne Thermal Emission and Reflection Radiometer (ASTER) Data in Geological Mapping. International Journal of the Physical 2011; 6: 7657-7668.

[9]. Okada K., Ishii M. Mineral and lithological mapping using thermal infrared remotely sensed data from ASTER simulator. International Geosciences and Remote Sensing symposium "Better Understanding of Earth Environment", 1993; 93:.126-128.

[10].Bedell R.L. Geological mapping with ASTER satellite: new global satellite data that is a significant leap in remote sensing geologic and alteration mapping. Special Publication, Geo. Soc. of Nevada, 2001; 33: 329-334. 
[11].Abdeen M.M., Allison T.K., Abdelsalam M.G., Stern R.J. Application of ASTER band-ratio images for geological mapping in arid regions; the Neoproterozoic Allaqi Suture, Egypt. Abstract with Program Geological Society of America, 2001; 3(3), pp.289.

[12].Velosky J.C., Stern R.J., Johnson P.R. Geological control of massive sulfide mineralization in the Neoproterozoic Wadi Bidah shear zone, southwestern Saudi Arabia, inferences from orbital remote sensing and field studies. Precambrian Research, 2003; 123 (2-4): 235-247.

[13].Hewson R.D., Cudahy T.J., Mizuhıko S., Ueda K., Mauger A.J. Seamless geological map generation using ASTER in the Broken Hill-Curnamona province of Australia. Remote Sensing of Environment, 2005; 99: 159-172.

[14].Rowan L.C., Mars J.C., Simpson C.J. Lithologic mapping of the Mordar, NT, Australia, ultramafic complex by using Advanced Spaceborne Thermal Emission and reflection Radiometer (ASTER) data. Remote Sensing of Environment, 2005; 99: 105-126.

[15].Gürsoy Ö., Kaya Ş. Detecting of Lithological Units by Using Terrestrial Spectral Data and Remote Sensing Image. Journal of the Indian Society of Remote Sensing,2016; 1: pp.1-11

[16].Kalkancı Ş. Şuşehri güneyinin jeolojik ve petrokimyasal etüdü. Kösedağ siyenitik masifinin jeokronolojisi (NE Sivas-Türkiye), 38. Türkiye Jeoloji Kurultayı Bildiri Özetleri, 1978; s. 33-34.

[17].Yılmaz A. Yukarı Kelkit Çayı ile Munzur Dağları arasının temel jeoloji özellikleri ve yapısal evrimi. T.J.K. Bülteni, 1985; 28/2, 79-92.

[18].Boztuğ D. Petrogenesis of the Kosedag Pluton, Susehri-NE Sivas, East-Central Pontides, Turkey. Turkish Journal of Earth Science, 2008; 17 (2): 241-262.

[19].Eyuboglu Y., Dudas F.O., Thorkelson D., Zhu D.C., Liu Z., Catterjee N., Yi K., Santosh M., 2017. Eocene granitoids of northern Turkey: Polybaric magmatism in an evolving arc-slab window system. Gondwana Research, 2017; 50: 311-345.

[20].Başıüyük Z. Hydrothermal alteration mineralogy-petrography and geochemistry of Eocene volcanics: an example from quadrangle of Zara-İmranli-Suşehri-Şerefiye (Northeast of Sivas, Central Eastern Anatolia, Turkey). PhD thesis, Sivas-Turkey, Cumhuriyet University, Institute of Science, 2006; pp.269

[21].Gürsoy Ö., Kaya Ş., Çakır Z., Tatar O., Canbaz O. Determining Lateral Offsets of Rocks Along The Eastern Part of The North Anatolian Fault Zone (Turkey) Using Spectral Classification of Satellite Images and Field Measurements. Geomatics, Natural Hazards and Risk, 2017; pp.1-13.

[22].Iwasaki A., Fujisada H., Akao H., Shindou O., Akagi S. Enhancement of spectral separation performance for ASTER/SWIR. Proceedings of SPIE, the International Society for Optical Engineering, 2001;4486, pp. 42-50.

[23].Iwasak1 A, Tonoka H. Validation of a crosstalk correction algorithm 371 for ASTER/SIWR. IEEE Transactions on Geoscience and Remote Sensing, 2005; 43: 2747-2751.

[24].Roberts D.A., Yamaguchi Y., Lyon R.J.P. Calibration of Airborne Imaging Spectrometer Data to percent reflectance using field spectral measurements: in Proceedings, Nineteenth International Symposium on Remote Sensing of Environment, Ann Arbor, Michigan, 1985 October 21-25

[25].Abrams M., Hook S.J. Simulated ASTER data for geologic studies IEEE Trans. Geosci. Remote. Sens., 1998; 33 (3): 692-699.

[26].Glenn N.F., Mundt J.T., Weber K.T., Prather T.S., Lass L.W., Pettingill J. Hyperspectral Data Processing for Repeat Detection of Leafy Spurge. Remote Sensing of Environment 2005; 95: 399-412.

[27].Mundt J., Glenn N.F., Weber K.T, Prather T.S., Lass L.W., Pettingill J. Discrimination of Hoary Cress and Determination of Its Detection Limits via Hyperspectral 
International Journal of Remote Sensing 8815 Downloaded by [Michigan State University] at 06:11 27 November 2013 Image Processing and Accuracy Assessment Techniques. Remote Sensing of Environment 2005; 96: 509-517.
[28].Thome K., Baggar, S., Slater, P. (2001). Effects of assumed solar spectral 464 irradiance on intercomparisons of earthobserving sensors. Proceedings SPIE, v.4540, pp. 260-269. 